\title{
Scanning electron microscopy of black flies \\ II. The hairs on dorsal cuticles of abdominal segments of larvae of 6 species from Japan
}

\author{
Kikuo MATSUO* and Kiichi Uemoto* \\ Department of Medical Zoology, Kyoto Prefectural University of Medicine, \\ Kyoto 602, Japan
}

(Received: May 16, 1975)

\begin{abstract}
The hairs on dorsal cuticles of the 6 th and 7 th abdominal segments of black fly larvae of 6 species belonging to Genera Prosimulium and Simulium are described and illustrated with the aid of a scanning electron microscope. The scanning electron micrographs are useful in distinguishing some, but not all, species.
\end{abstract}

The hairs on the abdomen of black fly larvae from Japan are generally not sclerotized and rather minute, unlike those of some African species (Crosskey, 1960), therefore it is not easy to observe them in detail with conventional light microscopes. In the first report of this series (Matsuo et al., 1974), the hairs on dorsal cuticles of the 6 th and 7 th abdominal segments of 8 species of black fly larvae from Japan were for the first time described and illustrated with the aid of a scanning electron microscope. The features described were useful in distinguishing some, but not all, species and seemed to have a taxonomic value among closely related subgenera.

In this $2 \mathrm{nd}$ report of this series the hairs on dorsal cuticles of the 6 th and 7 th abdominal segments of 6 additional species from Japan, Prosimulium (Prosimulium) kanii, Prosimulium (Prosimulium) kiotoense, Simulium (Eusimulium) konoi, Simulium (Eusimulium) mie, Simulium (Gomphostilbia) ogatai and Simulium (Wilhelmia) takahasii, are described with the aid of a scanning electron microscope. The specimens were collected from fields in Japan. The methods followed those used in the 1 st report of this series (Matsuo et al., 1974).

* 松尾喜久男, 上本龮一：京都府立医科大学医動物 学教室（宁 602 京都市上京区河原町広小路）

\section{RESULTS}

The characters of the hairs on dorsal cuticles of the 6 th and 7 th abdominal segments for distinguishing the larvae of 6 species of the present report and 8 species of the 1 st report of this series (Matsuo et al., 1974) are presented in Table 1.

\section{Prosimulium (Prosimulium) kanii Uemoto, Onishi et Orii, 1973}

Japanese name: Kani-obuyu.

Figs. 1-3.

Hairs on dorsal cuticle of 6 th and 7 th abdominal segments : barely visible at $300 \times$ magnification, long and short single hairs clearly recognizable at $1,000 \times$, both hairs slender and pointed; long hairs 28-48 micron long; short hairs 5-16 micron long; 11-20 short and $0-2$ long hairs present on $0.1 \mathrm{~mm}^{2}$ of surface area; at more than $2,000 \times$ minute hairs visible, single, broad and pointed, some dully pointed, $2-3$ micron long; 0-2 minute hairs present on $0.1 \mathrm{~mm}^{2}$ of surface area; in some specimens 2 minute hairs arise from a socket, slender and pointed, 4-5 micron long.

Source of larvae: Collected from Himuro, Kyoto Prefecture, March 1974. 
Table 1 Hairs on dorsal cuticle of 6 th and 7 th abdominal segments in black fly larvae of 14 species from Japan

\begin{tabular}{|c|c|c|c|c|c|c|c|c|}
\hline \multirow{4}{*}{ Species } & \multicolumn{7}{|c|}{ Single hairs ${ }^{1)}$} & \multirow{4}{*}{$\begin{array}{l}\text { Branched hairs } \\
\text { (No. branches) }\end{array}$} \\
\hline & long & \multirow{2}{*}{\multicolumn{2}{|c|}{$\frac{\text { short }}{\text { pointed }}$}} & \multicolumn{4}{|c|}{ minute } & \\
\hline & \multirow{2}{*}{$\begin{array}{l}\text { pointed, } \\
\text { slender }\end{array}$} & & & \multicolumn{2}{|c|}{ pointed } & \multirow{2}{*}{ blunt } & \multirow{2}{*}{ forked } & \\
\hline & & slender & broad & slender & broad & & & \\
\hline P. (P.) kanii & $+2)$ & + & - & \pm & + & - & - & - \\
\hline$P .(P$.$) kiotoense$ & + & + & - & - & + & - & - & - \\
\hline *P. (P.) yezoense & + & + & - & - & - & - & - & - \\
\hline S. (E.) konoi & + & + & - & - & - & - & - & $+(2-6)$ \\
\hline S. (E.) mie & + & + & - & \pm & - & - & - & - \\
\hline *S. (E.) subcostatum & + & + & - & - & - & - & - & - \\
\hline${ }^{*} S$. (E.) uchidai & + & + & - & - & - & - & - & - \\
\hline S. (Go.) ogatai & + & + & - & - & - & - & - & $+(2-5)$ \\
\hline *S. (Go.) omutaense & + & + & - & - & - & - & - & $+(2-10)$ \\
\hline *S. (Go.) shogakii & + & + & - & - & - & - & - & $+(2-7)$ \\
\hline S. (W.) takahasii & + & + & - & - & - & - & - & $+(2-5)$ \\
\hline${ }^{*} S .(G n$.$) bidentatum$ & + & + & - & - & + & - & - & - \\
\hline *S. (O.) aokii & + & + & + & - & - & - & - & - \\
\hline *S. (S.) quinquestriatum & + & + & - & - & + & + & + & - \\
\hline
\end{tabular}

1) Single hairs are divided into long, short and minute ones in each species. According to the species, long hairs vary from 20 to 80 microns, short hairs from 5 to 30 microns and minute hairs from 2 to 8 microns.

2) $+=$ present $;-=$ absent; $\pm=$ present in some specimens.

* From 1st report of this series (Matsuo et al., 1974).

\section{Prosimulium (Prosimulium) kiotoense Shiraki, 1935}

Japanese name: Miyako-obuyu.

Figs. 4-6

Hairs on dorsal cuticle of 6 th and 7 th abdominal segments : barely visible at $300 \times$ magnification, long and short single hairs clearly recognizable at $1,000 \times$, both hairs slender and pointed; long hairs 28-58 micron long; short hairs 5-20 micron long ; 10-22 short and 0-3 long hairs present on $0.1 \mathrm{~mm}^{2}$ of surface area; at more than $2,000 \times$ minute hairs visible, single, broad and pointed, sometimes dully pointed, 2-3 micron long; 0-2 minute hairs present on $0.1 \mathrm{~mm}^{2}$ of surface area.

Remarks: The hairs of this species are similar to those of $P$. (P.) kanii described in this paper. This species from Japan was formerly misidentified as Prosimulium hirtipes (Uemoto et al., 1973).
Source of larvae: Collected from Hirogawara, Kyoto Prefecture, April 1972.

\section{Simulium (Eusimulium) konoi (Takahasi, 1950)}

Japanese name: Kono-hososune-buyu. Figs. 7-8

Hairs on dorsal cuticle of 6 th and 7 th abdominal segments : well developed; numerous hairs visible at $100 \times$ magnification ; branched hairs and long and short single hairs recognizable at more than $300 \times$; branched hairs 2-6 branched, each branch slender and pointed, 5-26 micron long; long single hairs 40-55 micron long, short single hairs 15-25 micron long, both hairs slender and pointed; more than 80 branched hairs, 3-8 short single hairs and 0-3 long single hairs present on $0.1 \mathrm{~mm}^{2}$ of surface area.

Remarks: Only this species of the four 


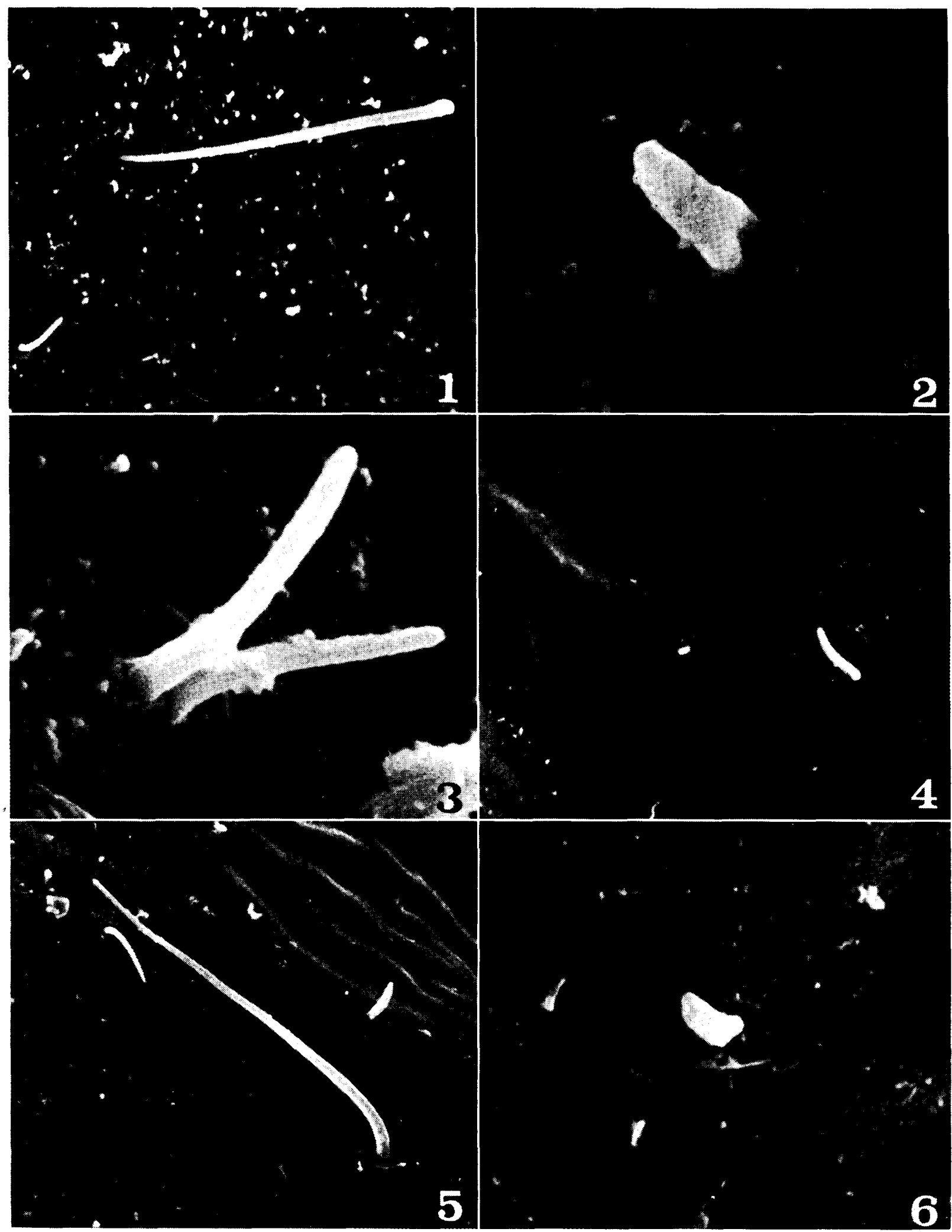

Fig. 1-3. $\quad P$. (P.) kanii, (1) $\times 1000$, long and short single hairs, $(2) \times 8000$, minute single hair, (3) $\times$ 10000, two single hairs arising from a socket. Fig. 4-6. P. (P.) kiotoense, (4) $\times 1000$, short and minute single hairs, $(5) \times 1000$, long and short single hairs, $(6) \times 5000$, minute single hair. 


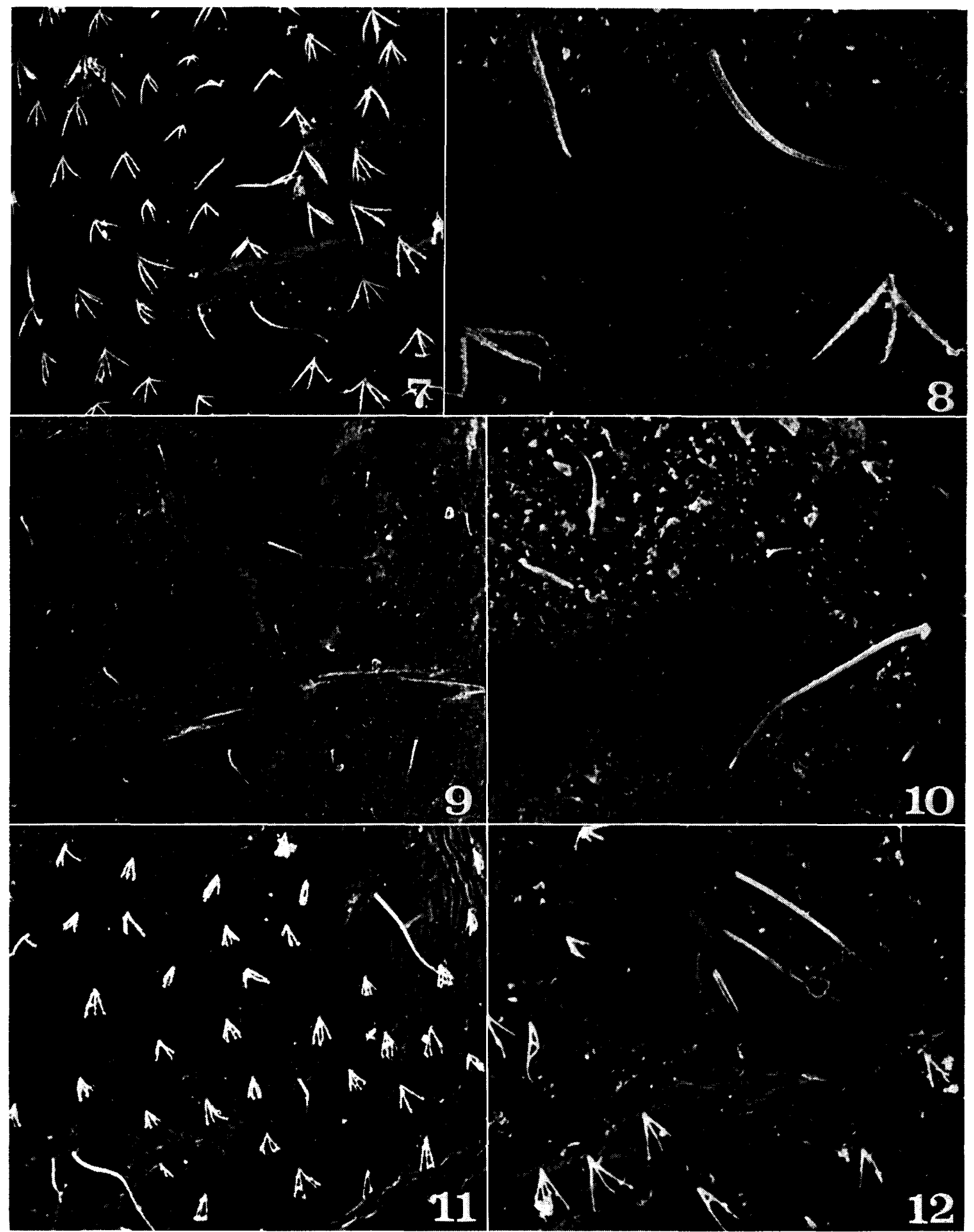

Fig. 7-8. S. (E.) konoi, (7) $\times 300$, long and short single hairs and branched hairs, $(8) \times 1000$, long and short single hairs and branched hairs. Fig. 9-10. S. (E.) mie, (9) $\times 300$, long single hair partially covered with dust and short single hairs, $(10) \times 1000$, long and short single hairs. Fig. 11. S. (Go.) ogatai, $\times 300$, long and short single hairs and branched hairs. Fig. 12. S. (W.) takahasii, $\times 1000$, long single hairs and branched hairs. 
belonging to subgenus Eusimulium described in this series has branched hairs on dorsal cuticle of abdominal segments of larvae and has larval antenna with secondary annulation on the second segment.

Souce of larvae: Collected from Jozankei, Hokkaido, June 1974.

\section{Simulium (Eusimulium) mie Ogata et Sasa, 1954}

Japanese name: Mie-tunomayu-buyu. Figs. 9-10

Hairs on dorsal cuticle of 6 th and 7 th abdominal segments: barely visible at $300 \times$ magnification; long and short single hairs clearly recognizable at more than $500 \times$, both hairs slender and pointed; long hairs 27-45 micron long, short hairs 11-16 micron long; 0-2 long and 18-35 short hairs present on $0.1 \mathrm{~mm}^{2}$ of surface area; in some specimens, minute hairs recognizable, single, slender and pointed, about 2.5 micron long.

Source of larvae: Collected from Oharano, Kyoto Prefecture, November 1973.

\section{Simulium (Gomphostilbia) ogatai (Rubzov, 1962)}

Japanese name: Ogata-tunomayu-buyu. Fig. 11

Hairs on dorsal cuticle of 6 th and 7 th abdominal segments: well developed; numerous hairs visible at $100 \times$ magnification; branched hairs and long and short single hairs recognizable at more than $300 \times$; branched hairs 2-5 branched, each branch slender and pointed, 5-15 micron long; long single hairs 50-66 micron long, short single hairs 15-22 micron long, both hairs slender and pointed; more than 80 branched hairs, 4-9 short single hairs and $0-3$ long single hairs present on $0.1 \mathrm{~mm}^{2}$ of surface area.

Remarks: All three species, this species, $S$. (Go.) omutaense and $S$. (Go.) shogakii, belonging to subgenus Gomphostilbia described in this series have numerous branched hairs on dorsal cuticle of abdominal segment of larvae and have numerous hairs on katepisternum of adults.

Source of larvae: Collected from Himuro, Kyoto Prefecture, October 1974.

\section{Simulium (Wilhelmia) takahasii (Rubzov, 1962)}

Japanese name: Uma-buyu.

Fig. 12

Hairs on dorsal cuticle of 6 th and 7 th abdominal segements : well developed; numerouse hairs visible at $300 \times$ magnification ; branched hairs and long and short single hairs recognizable at more than $500 \times$; branched hairs $2-5$ branched, each branch slender and pointed, 3-9 micron long; long single hairs 22-39 micron long, short single hairs 5-8 micron long, both hairs slender and pointed; 1-10 short single hairs, 0-2 long single hairs and more than 100 branched hairs present on $0.1 \mathrm{~mm}^{2}$ of surface area.

Remarks: In having branched hairs, this species is similar to $S$. (Go.) ogatai, $S$. (Go.) omutaense, $S$. (Go.) shogakii and $S$. (E.) konoi described in this series, but the branched hairs are generally shorter in this species. This species from Japan was formerly misidentified as $S .(W$.$) salopiense (Taka-$ hasi, 1973).

Source of larvae: Collected from Makino, Shiga Prefecture, October 1974.

\section{ACKNOWLEDGEMENT}

We thank Mr. O. Onishi of Center of Epidemic Prevent, Kyoto for his help in the collection.

\section{REFERENCES}

Crosskey, R. W. (1960): A taxonomic study of the larvae of West African Simuliidae (Diptera: Nematocera) with comments on the morphology of the larval black-fly head. Bull. Brit. Mus. Nat. Hist. (Ent.) $10: 1-74$.

Matsuo, K., Y. Yoshida, I. Kunou and K. Uemoto (1974) : Scanning electron microscopy of black flies. I. The hairs on dorsal cuticles of abdominal segments of larvae of 8 species from Japan. $J$. Kyoto Pref. Univ. Med., 83 : 283-291.

Takahasi, H. (1973): On scientific name of the specimens identified as Umabuyu in Japan. Jap. J. Sanit. Zool., 23: 277 (in Japanese).

Uemoto, K., O. Onishi and T. Orii (1973): Revision of the Genus Prosimulium Rouband (Diptera, Simuliidae) of Japan. I. hirtipes- group in the Subgenus Prosimulium. Jap. J. Sanit. Zool., 24: 27-46. 


\section{摘 要}

ブユの走查電子顕微鏡的研究 第 2 報

日本産 6 種幼虫の腹部背面毛

日本産ブニ 6 種幼虫の腹部第 6,7 節背面毛を走查電
子顕微鏡で観察し，その形態を記述した。 そして既報種 を含め日本産14種の幼虫について腹部第 6,7 節背面毛 の異同を表記した。 